Živko Kulić, PhD, ${ }^{*}$

Full Professor,

Faculty of Law, Megatrend University

Goran Milošević, $P h D,{ }^{* *}$

Full Professor,

Faculty of Law, University of Novi Sad

Luka Baturan, PhD, ${ }^{* * *}$

Senior Assistant,

Faculty of Law, University of Novi Sad
ПРЕГЛЕДНИ НАУЧНИ РАД

doi:10.5937/zrpfni1878149K

UDK: 331.105.24(497.11)

Рад примљен: 17.12.2017.

Рад прихваћен: 04.03.2017.

\title{
LABOUR MARKET AND COLLECTIVE BARGAINING IN THE REPUBLIC OF SERBIA
}

\begin{abstract}
Despite proclaimed equality and parity of subjects in a labour market, workers are actually a weaker party within the system of collective bargaining. Their position in negotiations and negotiating of work and employment terms cannot be made equal with the position of the holders of capital, particularly in cases of collective bargaining with an employer. Along with the rising level of collective bargaining, the position of labour/ trade union negotiating party gets stronger as well. The union power comes to the fore less when bargaining at the level of employer than at the sectoral or national level. At the higher levels of collective bargaining, the unions are more successful in protecting the rights and interests of workers. The process of collective bargaining influences the labour market as well. This influence is particularly noticeable in small or insufficiently developed economies, such as the economy of Serbia.
\end{abstract}

Key words: union, employee, employer, collective bargaining, collective agreement, regional development.

*zivko.kulic@yahoo.com

**gmilosevic@pf.uns.ac.rs

***lbaturan@pf.uns.ac.rs 


\section{Introduction}

Efficiency, ${ }^{1}$ growth, ${ }^{2}$ development, ${ }^{3}$ stability ${ }^{4}$ and justice ${ }^{5}$ are the basic goals of economic policy that countries may set for themselves. Among these goals is often a tradeoff effect, which means that achieving one goal excludes the achievement of another. One of the basic economic problems existing in Serbia nowadays is high unemployment rate and low wage rates. In order to achieve full employment, it is necessary to achieve gross domestic product growth that would enable to employ the existing working age population which is currently unemployed. One of the assumptions of economic growth is to enable efficient use of available resources, i.e. productive ${ }^{6}$ use of every factor of production. This, among other things, means the possibility to achieve the highest production value possible from one unit of work used, in other words to achieve the set level of production with the cheapest labour possible.

Economic efficiency and growth require the most flexible legal framework so that the subjects in the market (employers and workers) would harmonize their relationship in the easiest manner. However, if observed from the point of view of Serbia, this could mean easy layoffs of the already employed workers and lowering the wage rates which are in the existing conditions already so low that they bring into question the possibility to meet the bare necessities of life, which is often considered unjust and politically unacceptable. In such a situation, there is a huge pressure of the electorate on political management for these problems to be alleviated and solved as much as possible.

Achieving economic and other set goals, among other things, means good relationship between employers and employees. Unfortunately, these relations are not always satisfactory, which is negatively reflected both on individual and organizational success. This is why it is very important for labour disputes, involving disputes and disagreements between employers and employees, to

1 Economic efficiency means optimum use of available resources.

2 Economic growth is an increase in the scope and value of production which is measured by gross domestic product.

3 Economic development is a dynamic process that in addition to economic growth and structural changes in economy includes also the changes in income distribution which contribute to the increase of standard of living.

4 Economic stability refers to a situation in which gross domestic product is stable or is growing along with high employment rate and low inflation rate.

5 There is no universally applicable definition of justice. In economic theory justice is most often observed alternatively as a socially acceptable outcome of distribution or the process of distribution.

6 Productivity is the ratio of the total output product and engaged input of factors of production. 
be settled in a peaceful and democratic manner in accordance with the law. Collective bargaining is one of key preconditions to settle the relations between the representatives of labour and the representatives of capital in a sustainable and mutually acceptable manner. Collective bargaining thus creates necessary assumptions for successful overcoming of tensions and possible differences between social partners, and more permanent preservation of social peace in the interest of all parties concerned.

The negotiations between workers and employers can be conducted on a wide range of topics depending on specific needs and interests of negotiating parties. These are the questions most often related to trade union security, preservation of social peace, participation of employees and employment terms and conditions (wages, salaries, working hours, vacations and leaves of absence, transfer to another workplace, training of employees, promotion system, forced leave of absence, layoffs, safety at work, work discipline, disciplinary and material responsibility, and alike). The subject of bargaining and collective-agreement regulations can also include other important matters in accordance with the law and interests of the representatives of labour and capital, respectively.

Collective bargaining is conducted between employers and employees in order to reach a collective agreement which regulates the conditions of labour and employment. It operates at all levels of union and employment organization and operation, in other words, from the level of employer or the unit of local self-government up to the highest national level. Although the International Labour Organization calls for the collective bargaining to spread to include all employers and all employees, the fact is that it has not yet happened in many countries, including Serbia.

The existing condition in the field of collective bargaining in the Republic of Serbia is not satisfactory, although it is somewhat more favourable than it used to be in the past. The reasons for this are both objective and subjective. Some can be eliminated in a relatively easy and fast manner, but others cannot. This is why it is very important to recognize them properly and to find the appropriate solutions to overcome them with the participation of all interested parties.

\section{Labour Market Equilibrium}

In order to examine the economic effects of a legal standard regulating the system of collective bargaining, we should go back to the beginning and examine the basic mechanisms of labour market functioning. Economic analysis will then focus on the influence of legal and other regulations in the field of collective bargaining on employers and their businesses, particularly from the point of view of labour allocation. 
Correlation and intertwining of production functions now, more than ever before, require to include a man and his intellectual and other potentials into the working process. Human labour is of crucial significance for achieving a company's projected goals. However, no matter how perfect human labour is, it has its limitations. There is a natural limit of human endurance. A man can work from 12 to 16 hours a day, after which he needs to rest. As a conscious and rational being, man makes work-related decisions as well as the decisions on the place of work. As a rule, the level of earnings or salary influences this decision, particularly in poor societies such as ours. Higher monthly income means more favourable working conditions and vice versa (Milošević, 2016: 251).

Natural limitation and socio-economic working conditions influence the supply of labour. The labour supply curve is upward sloping. Among other things, this means that, in case of higher wages, the unemployed strive to find a job as soon as possible, while the employed are interested in working more hours than usual. Contrary to this, in case of lower wages the employed are less interested in longer working hours, and the unemployed are interested in seeking jobs. Labour supply is also influenced by demographic factors, real wage level, the measures of social policy, trade union organizing, the condition of social partnership and other factors (Milošević, 2016: 251).

Unlike the labour supply curve, the labour demand curve is downward sloping. Labour demand is determined by the employers. They include manufacturers who combine production factors (work, capital and natural resources) and transform them into useful forms (products, outputs) in order to maximize their own profit. For them, the labour price is a significant parameter value which is formed in the market when demand and supply meet. This is why the employer decides only on the scope of production at the given labour price. What's more, he hires additional personnel until marginal product of labour (or marginal revenue) becomes equal with marginal cost (Baturan, Maksimović, Đuričić, 2014: 386-387).

The demand for human resources depends largely on productivity of work and the price of labour. The demand for labour is derived in the same way as the demand for any other resource since it depends on the demand for a product or service in whose manufacturing or rendering it participates. Accordingly, the labour demand depends on the productivity of work in manufacturing a certain product and the market value (price) of that product (the more productive the labour and the more expensive the product of such labour, the greater and more certin the demand for such labour or product, as a rule). 
Figure 1: Labour market equilibrium

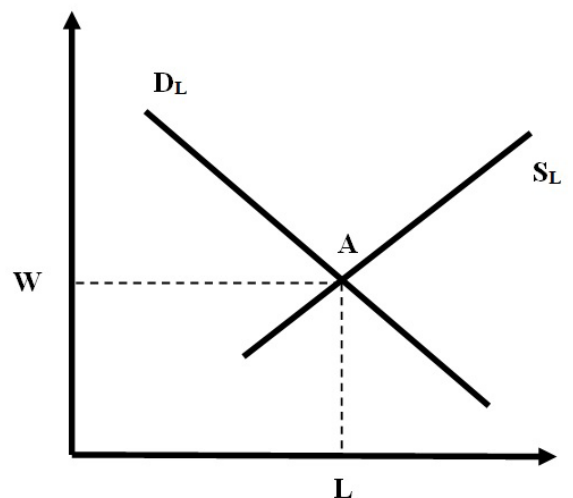

Labour market equilibrium is established at the point where labour supply $\left(\mathrm{S}_{\mathrm{L}}\right)$ and labour demand curves $\left(D_{L}\right)$ intersect (Figure 1). The point of equilibrium (A) represents equilibrium level of wage (W). At that level, labour supply and demand are in equilibrium: all those seeking jobs are employed and all positions are filled (Begović, Labus \& Jovanović, 2011: 467). If the wage is above the equilibrium level, the manpower supply exceeds the demand; in other words, the labour supply exceeds the demand, and the demand for labour is less than optimum. This means that there is excess supply of labour. In other words, this means that the problem of unemployment occurs. ${ }^{7}$ In such a situation, there is a possibility to increase wage in order to improve the position of both employers and employees to the mutual benefit.

\section{Significance of Collective Bargaining}

At the competitive market of production factors, in order to make an optimum choice, the employer is required to select the most desirable set of factors. The employer wants an optimum choice, i.e. such a combination of production factors (labour, capital, natural resources) which will provide the highest benefit within a given budget limit. However, in real life, the labour market is not perfect since there are limitations both on the side of supply and on the side of demand, respectively. In addition to economic issues, the questions relating to labour have a significant political dimension since workers make a considerable part of the electorate. This is why they use their trade union, political and other organiza-

7 Contrary to this, if the wage is below the level of equilibrium, there is shortage of the employees. This shortage can most efficiently be eliminated by the increase of wage up to the level of equilibrium. 
tions to exert pressure on the politicians in order to get certain privileges they would not get in the market otherwise. Employers do the same thing. Although according to the Constitution the economic system in Serbia is based on free market, ${ }^{8}$ although everyone has equal legal status on the market, ${ }^{9}$ although all acts are prohibited that restrict free competition by creating or abusing monopolistic or dominant status, ${ }^{10}$ the fact is that the impact of market economy on social and economic status of the employed is actually reflected on, or is achieved through, the dialogue between trade unions and employers. ${ }^{11}$

Labour supply, among other things, is also influenced by labour organizing into trade unions. On the side of the labour demand, there are employers, or associations of employers. The presence of trade unions and employers' associations imposes the need for a dialogue and collective bargaining, which, according to the opinion of some authors, primarily in the field of economic sciences, is contrary to the model of perfect competitive labour market. The second question is whether it is always like this, first of all because the things must be observed within a wider context.

Collective bargaining is conducted in order to reach a collective agreement on employment and to regulate the matters which are considered key assumptions for providing social peace and stable economic conditions. In the negotiating process, negotiating parties make efforts to reach compromises and mutually acceptable solutions regarding the issues negotiated about. However, such efforts do not always lead to the desired result. Since the interests of the negotiating parties are basically mutually opposed, compromise solutions are not easy to achieve. There are occasional disputes between the negotiating parties over how certain maters are regulated. The experts, particularly legal experts, most often consider such disputes as collective labour disputes or industrial disputes (Kulić, 2003: 132).

During negotiations, negotiating parties attempt to solve disputed matters in an informal way. The principle of informal negotiations encourages efficiency, considering that the representatives of labour and capital are given the possibility to solve disputed matters on their own, i.e. to reduce transaction costs at the satisfactory level. Solving disputes in such a way makes it possible to avoid complicated and, often, hardly understandable procedural rules characteristic for collective labour disputes using formal methods. In addition, it should be noted

8 Constitution, Art. 82 par. 1

9 Constitution, Art. 84 par. 1

10 Constitution, Art. 82 par. 2

11 Constitution, Art. 82 par. 3 
that informal methods help in faster overcoming of disputes between employers and employees, which is particularly important in the negotiating process.

If the disputed issues are not resolved in an informal manner, the disputing parties are left the possibility to try to resolve them by formal methods. Resolving the disputed matters by formal methods is most often institutionalized. Such dispute resolution between the capital owners and employees provides greater security in protection of their collective rights and interests and contributes to further humanization of production relations. ${ }^{12}$ Collective bargaining and collective agreements provide for more rights and more favourable employment terms and conditions to the benefit of the employed in comparison with the rights and conditions determined by the law. The lower the level of collective agreement concluded, the higher the rights provided by it, for which reason it is very important to conduct negotiations at all levels at which collective agreements are concluded or may be concluded.

Successful collective bargaining and concluding of collective agreements is not only in the interest of the employed but also in the interests of employers. This is also confirmed by the fact that concluding the collective agreement contributes to: a) more permanent preservation of social peace; b) reducing tensions between partners; c) increasing work satisfaction and motivation for work; d) increasing work productivity and savings; e) increasing work results, etc.

These reasons point to the importance of creating legal and other necessary assumptions for further strengthening and improvement of the collective bargaining system in Serbia. It is in the interest of not only employers and the employed but also in the interest of the society as a whole. Besides constant strengthening of social partnership and tripartite cooperation, this entails other corresponding assumptions, both legal and economic, as well as educational, sociological, psychological, and others. ${ }^{13}$

12 Collective bargaining is the basis of social dialogue as one of key preconditions of successful and uniform development of a contemporary society. Without collective bargaining there is no real social partnership. If collective agreements are lacking, there is neither industrial nor political democracy too.

13 In connection with this, we shall further elaborate the difficulties that participants in collective bargaining negotiations most often face in Serbia, in order to contribute to their thorough comprehension and faster overcoming in the interest of employers, the employed, state and society as a whole. 


\section{Collective Bargaining and Partnership}

\section{Equilibrium in the Labour Market}

It is evident that employees (as individual) as well as trade unions play an active role in the process of collective bargaining. Therefore, labour supply curve of the workers organized in a trade union is not individual but collective labour supply curve. Negotiating power of workers increases through collective bargaining, which is why it is logical to conclude that collective bargaining as a rule provides for more rights and more favourable employment conditions for the employees than the rights and conditions provided for by individual negotiations. This is exactly why the collective labour supply curve is always and only above the individual labour supply curves (Veselinović, 2010: 180). The relationship between individual $\left(\mathrm{S}_{\mathrm{L}}\right)$ and collective $\left(\mathrm{S}_{\mathrm{kp}}\right)$ labour supply curves and the influence of collective bargaining on the equilibrium at labour market are shown in Figure 2.

Figure 2: Collective bargaining and labour market equilibrium

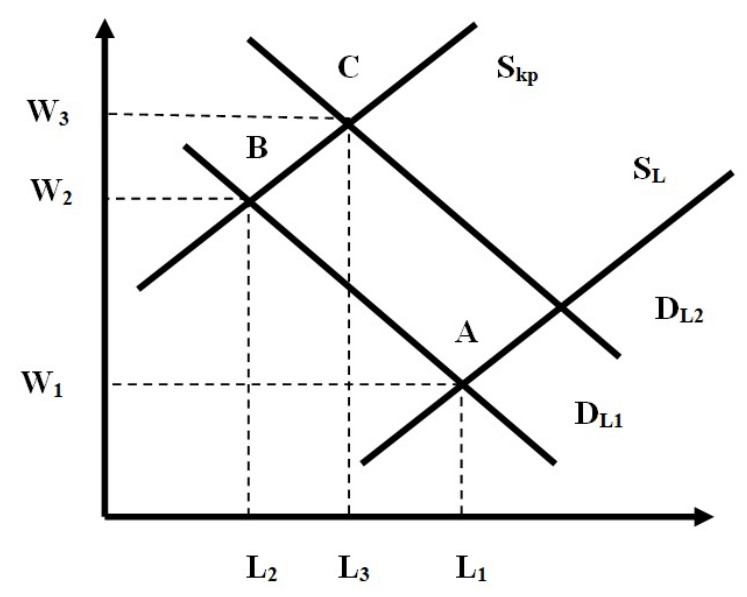

When there is no collective bargaining, the equilibrium in the labour market is established at W1 wage. In that case, the number of employed workers stops at level L1, as previously explained. The differences in national regulations related to the system of collective bargaining, as a rule, contribute to achieving various effects on the equilibrium established in the labour market observed from both qualitative and quantitative point of view. 
If the legal solutions contained in the collective agreement do not provide for redistribution of income but only make the process of individual negotiations easier, which is not always the case, then collective bargaining does not influence the allocation of labour in the market. On the contrary, the solutions drafted in such a way only lower the transaction costs of negotiations. Such ("flexible") solutions enable the contracting parties to harmonize their rights and obligations in direct negotiations in an easier and better way, adapting their relations to market economic conditions.

However, using the system of collective bargaining, the state often attempts to redistribute resources from workers to employers, and vice versa. Such solutions impose to the employers various obligations regarding workers, including the obligations which they would not have to agree to in individual negotiations. Due to legal limitations, both employers and workers are not always able to adequately adapt to market conditions, which disturbs the allocation of labour as a factor of production.

Such ("inflexible") system of collective bargaining often produces artificial growth of wages from equilibrium level (W1) to a higher level W2. The growth of wages (as wage rates paid by the employers) contributes to (artificial) improvement of material position of the employees. However, this mostly worsens the position of employers, who consequently decrease their labour supply by adapting it to new market conditions (the new level of demand is marked by $S_{k p}$ curve on the graph).

The new equilibrium is established at point B. Supply and demand are equalized at lower level (L2). The difference between L2 and L1 represents the increase of unemployment which is the result of the nature and result of collective bargaining. All in all, it can be concluded that opportunity costs, which occurred in order to improve the position of the employees, worsen the position of employers as well as the position of a part of workers who most often lose jobs.

Economic analysis of market labour equilibrium in the conditions of collective bargaining with unchanged demand leads to the following conclusions:

- Market labour equilibrium is above individual labour equilibrium (W2 wage is above W1 wage);

- Employment is lower in relation to employment under the conditions of individual negotiations (employment L2 is below L1);

- Increase of unemployment (difference between L2 and L1) means that the workers who were part of collective bargaining system (workers who lost jobs) are forced to seek jobs (such state of affairs leads to increased supply of labour and drop of wages, and the collective bargaining provides for more 
favourable employment conditions and better wages than the conditions and wages determined by the employment contract, i.e. the system of individual negotiations);

- Individual labour supply is below collective supply which is influenced by trade unions.

- If the increase of labour demand in the market results due to the conditions of collective bargaining, various processes occur, or they may occur:

- There is an increased number of negotiating options for trade unions, so that the expected outcome of negotiations is more favourable as compared with individual position of labour;

- Labour market equilibrium is above individual labour equilibrium (W3 wage is above W1 wage);

- Employment shows a tendency of growth (from L2 it grows to L3), depending on negotiating power of trade unions and labour demand.

\section{Collective Bargaining in the Republic of Serbia as a Factor of Optimum Resource Allocation}

Labour legislation of the Republic of Serbia envisages relatively good and flexible solutions related to the system of collective bargaining. Such solutions provide for economic and other subjects in the market to achieve efficient allocation of labour as a production factor.

A collective agreement must not contain provisions which give less rights or set less favourable employment conditions than the rights and conditions determined by the law. ${ }^{14}$ And vice versa, a collective agreement can stipulate only more favourable employment conditions (which, among other things, have impact on increased wage rates payed by the employer). However, what is important is that according to the solution contained in the Labour Act, the employer is obliged to bargain..$^{15}$ There is not a single provision that forces him to conclude a collective agreement and give more rights to the workers than he wants or can bear.

According to the solutions contained in the Serbian labour-law regulations, the participants in collective bargaining are obliged to bargain but not to conclude a collective agreement. Negotiating parties cannot be forced to accept certain solutions during negotiations, nor to conclude a collective agreement. Whether

14 Labour Law, Art. 8, par. 1.

15 According to Article 254, paragraph 1 of the Labour Law, "the participants in the procedure of concluding a collective agreement shall be obliged to bargain". 
the agreement will be concluded or not, and what provisions it will contain, depends on their needs and interests, and this rule must be respected. Such a solution is largely favourable in terms of achieving economic efficiency since it enables both workers and employers to harmonize directly their needs and interests in the best manner possible. If there is a mutual interest, employers will be able to find common grounds with workers within the existing institutional framework. It is obvious that the obligation to participate in negotiations does not imply transaction costs ${ }^{16}$ on the part of employers who, as they see things, do not have particular interest in concluding a collective agreement. Namely, a transaction cost does not exist because the law does not provide for any sanction for such a behaviour. However, considering that the Labour Act does not prescribe sanctions for such an action by the employer, it can be argued that even this "obligation" is not the obligation which will be sanctioned in case it is not fulfilled. ${ }^{17}$ Legal regulations are such that they do not request to punish the negotiators who are not willing for some reasons to conclude a collective agreement, even though they participate in collective bargaining. In such a situation, the employer regulates the conditions of work and employment independently, taking into account the legitimate rights, interests and expectations of the employees.

Economic analysis of the Labour Act presents a dilemma regarding the issue of allocation efficiency in terms of Article 257 of the Act. Under this Article, the Government has the possibility to determine that a collective agreement or some of its provisions also apply to employers who are not members of the employers' association which is a participant in the collective agreement. The Government may make such a decision in order to achieve the economic and social policy, in order to ensure equal working conditions which represent the minimum rights of employees, or to mitigate the differences in earnings in a particular branch, group, subgroup, or activity which significantly affect the social and economic position of employees, consequently resulting in unfair competition, provided that the collective agreement whose effect is being extended obligates employers who employ more than $50 \%$ of the employees in a particular branch, group, subgroup, or activity. ${ }^{18}$

16 Costs related to transactions, in other words the activity or a set of activities necessary to do in order for a certain product or service to transit the boundaries of an organization or a part of organization are called transaction costs (costs of transition).

17 If they do not conclude a collective agreement, the participants in collective bargaining negotiations can set up arbitration in order to solve the disputed matters. However, if the agreement is not concluded even after the arbitration has been set up, no one will bear consequences of such a decision.

18 The provisions of Article 257, paragraphs 1 and 2 of the Labour Law, prescribe that at the request of an employer or an association of employers the Government may decide that 
According to one standpoint, this solution is inadequate because it disrupts the principles of free decision-making, the rule of competitiveness, the right to choice, and free market operation. It further entails disrupting the conditions of work and business operations, which is of vital importance for work and functioning of economic and other subjects in every country. Such a legal solution results in providing more favourable position to certain legal subjects (as a rule, provided by the state) and destabilizing competitive subjects, which disrupts the optimum resource allocation.

According to another standpoint, the authority of the Government to decide if the collective agreement or some of its provisions are also applicable to the employers who are not members of the employers' association which is a paticipant in the collective agreement is a good solution. The proponents of this standpoint consider that in certain periods, when there is evidently no equilibrium in labour market, the state must use its measures to regulate the market. In the conditions of disrupted market regularity, which results in unfair competition and destruction of social status of employees, not a single state or Government can allow themselves such a luxury to let economic flows in the market ensue without their interference. The state measures are not aimed at devastating the economic environment; in fact, they establish standards to support certain flows which would re-establish the disrupted equilibrium in the labour market in the interest of not only the employees but also the society as a whole. In this way, the state establishes the system of optimum resource allocation. When the equilibrium in the market is re-established, there will be no more need for excessive interference of the state in market economic conditions.

\section{Problems Significant for the Labour Market, most Frequently Faced by the Participants in Collective Bargaining in Serbia}

Although in the last fifteen years there have been certain improvements of the system of collective bargaining in Serbia, the fact is that there are still problems that the negotiating parties encounter almost on a daily basis. Their existence makes negotiating process complicated and difficult, including partially even the conclusion or the application of collective agreements as well, which is not in the interest of either employers or employees. There are multiple reasons for such a condition but, basically, they include:

a collective agreement from Article 257 of the Law will not be applied to some employers or associations of employers in the part related to earnings and compensation of earnings. Pursuant to the provisions of Article 258, paragraphs 1 and 2 of the Law, an employer or association of employers may submit a request for exemption from implementation of a collective agreement with the extended effect, should due to financial and business results they be unable to implement the collective agreement. 
- the problems occurring during the negotiating process;

- the problems pertaining to the conclusion of a collective agreement;

- the problems during the implementation and interpretation of a collective agreement, and

- the problems related to the participants in collective bargaining, or conclusion of a collective agreement, both on the side of employers and on the side of employees (organization, representation, autonomy, number of participants, etc.)

\subsection{The problems occurring during the negotiating process}

The system of collective bargaining is based on the negotiating process. For this reason, it is very important for the negotiations to be conducted in the right manner and in good faith. Unfortunately, this is not always the case. The problems most often occurring during negotiations are as follows:

- disagreements on initiation of collective bargaining;

- dilemmas about the structure, number of participants and modus operandi of a negotiation board; and

- vagueness related to the participation, status and role ${ }^{19}$ of the founders in collective bargaining.

1) Disagreements on initiation of collective bargaining are rather frequent. The reasons for this most often include: a) vagueness regarding which party should initiate, i.e. start the negotiation process; b) disputes related to drafting the collective agreement, whose content should be negotiated (for instance, who should draft it: a collective bipartite body, the initiator of the procedure, each party respectively, or an independent expert body), or disputes regarding the use of the existing or earlier text of a collective agreement as a starting point for negotiations; c) disputes on the venue and time of negotiating meetings: the venue where negotiations are conducted should be "a neutral ground", and the negotiating process should be conducted during or at the expense of working hours and not during free time of the employees.

2) Dilemmas about the content, number of participants and modus operandi of a negotiation board are particularly pronounced and very current topic for both

19 Participation of founders in collective bargaining, or concluding of a collective agreement in Serbia is a relevant matter only in case the negotiations are conducted in order to conclude a separate collective agreement for public enterprises, for-profit corporations founded by a public enterprise and public services, or a collective agreement with employers for such enterprises, corporations and public services. 
negotiating parties at all negotiating levels. Such dilemmas are especially highlighted if a negotiating party includes several participants, i.e. several representative trade unions and/or several representative associations of employers. ${ }^{20}$ The dilemmas exist because there is a lack of legal regulations pertaining to the structure of a negotiating board and representation in it, the number of negotiating board members and manner of work of a negotiating board.

3) Vagueness related to the participation, status and role of the founders in the collective bargaining which is conducted in order to conclude a collective agreement with employers for public enterprises, corporations founded by a public enterprise and public services result from the fact that these matters are not regulated in a satisfactory manner.

\subsection{The problems regarding the conclusion of a collective agreement}

Various problems may occur regarding the conclusion of a collective agreement. As a rule, they boil down to three questions as follows: a) Can a collective agreement be concluded in case some of participants in collective bargaining agree to it, and some of them disagree with it? b) Can the collective agreement be concluded in case a certain number of matters is not harmonized, so that its provisions regulate only the harmonized matters? c) Is the founder the signatory to a collective agreement?

1) The question concerning the possibility of concluding a collective agreement in case where only some participants in collective bargaining agree to it deserves special attention. The courts in Serbia mostly have negative opinion on this issue, which is among other things due to the fact that there are no legal solutions that would oblige them to act otherwise. Although there are reasons which could be used to justify such stance and practice, the fact is that the arguments suggesting the need for different even opposite reasoning and acting are stronger, more rational and closer to life needs. ${ }^{21}$

The way out from the said state of affairs should be sought in determining the rules according to which a collective agreement could be concluded even in case one or more participants in negotiations disagree with it, naturally, on condition that participants in negotiations interested in its conclusion gather the majority of membership, i.e. enjoy a higher degree of representation than

20 They are not relevant for employer's side only if negotiations are conducted in order to conclude a collective agreement at the employer's seat of business.

21 The stated approach among other things starts from the number of members, i.e. the degree of representation of participants in negotiations. For instance, the participant with the lowest percentage of membership without rational and justified reasons blocks the negotiating process, thus making it impossible to reach a positive outcome. 
the participants who are opposed to the conclusion of the collective agreement. This is even more so if they do not have reasonable, rational and objectively acceptable reasons to act like this. It would be the best if such rules, at least the basic ones, are prescribed by the law.

2) Dilemma related to the possibility to conclude a collective agreement in case a certain number of matters are not harmonized so that its provisions would regulate only the harmonized matters. Collective agreement can always be concluded to cover the matters that are harmonized, especially if the number of the unharmonized matters is inconsequantial, and if it is estimated that their harmonization would not last long. Once these matters are harmonized, it is possible to conclude a new collective agreement or make an annex to the existing one concluded earlier. ${ }^{22}$

3) The founder is a signatory to the collective agreement, but not every agreement. This matter does not deserve much attention considering that it is closely regulated by the Labour Act. Regardless of whether the founder appears as an independent negotiating party or in the role of one of participants in negotiations at the employer's party, the founder is one of the participants in concluding a collective agreement. Consequently, he is also one of the signatories to the agreement, which cannot be questioned. ${ }^{23}$

\subsection{The problems during the implementation and interpretation of a collective agreement}

There are numerous problems during the implementation and interpretation of collective agreements in practice. They most often relate to disagreements regarding the amount, manner of calculation and schedule of payment of wages or salaries, their compensation, and other income of employees. There are thousands of arbitrations, court and other proceedings or disputes regarding such questions. The disputes usually arise due to various interpretations and wrong implementation of provisions referring to the manner of calculation of compensation for overtime work, night shifts, work hours during state holidays or other

22 The number of collective agreements which can be concluded at the level of employer as well as at higher levels of collective bargaining is not limited, which additionally supports the presented attitudes and assessments.

23 Pursuant to the provisions of Articles 246 and 247 of the Labour Act, a founder is an independent negotiating party and one of the participants in concluding, i.e. signing a collective agreement in case a separate collective agreement is concluded for public companies, corporations established by the public company and public services, and one of the participants in concluding a collective agreement at an employer, i.e. one of the participants in its signing, if a collective agreement is concluded at an employer relating to public companies, corporations established by the public company and public services. 
non-working days, work in shifts, payment of jubilee prizes, subsidies for the use of annual leave, charges for meals at work, travelling expenses, etc. The number of disputes could be considerably reduced if the participants in concluding a collective agreement would be more precise in defining their relationship, and if the legal norms would be clearer, more specific and more comprehensive, which is not always easy to achieve.

\section{Instead of a Conclusion}

Collective bargaining is a dynamic process which leads to the agreement between employees (trade unions) and employers on wages, salaries, benefits, holidays and other conditions of labour and employment. Negotiations are conducted between two parties, i.e. between the representatives of the employer and the employees. Depending on the level at which a collective agreement is concluded, they can be conducted at the level of the employer, at the level of a unit of territorial autonomy or local self-government, at the level of economic branch or activity, at the national level and at the international level. The participants in negotiations endeavour to protect the interests of their negotiating party to the maximum. Trade union representatives represent the interests of their members, trying to get the best solutions acceptable for the employees. On the other hand, the employers' representatives represent the interests of the owners of capital, fighting for the solutions acceptable for them.

The negotiating philosophy implies high level of independence and autonomy of negotiating subjects, but also willingness to find compromises acceptable for both sides. Readiness to seek and find such solutions results from economic and social reality, negotiating maturity and responsibility of social partners. To a certain extent, negotiating philosophy implies a relative balance of negotiating power which should be provided by labour legislation, but which should also be fought for and achieved by social partners in their everyday relations.

The instruments of collective bargaining in Serbia have been improved over time and valuable negotiating experience has also been gained. Negotiating parties manage the negotiation process better than ever before. The members of negotiating teams know what they want and they approach negotiations with more knowledge and skills, which was not the case in the 1990s, for instance. Therefore, the positive shifts are visible in all segments of collective bargaining, which is an encouraging and very significant fact.

Yet, thee is a need to overcome and improve the existing state of affairs in the area of collective bargaining in Serbia. Among other things, it implies implementation of certain measures to change things for the better. Such measures include: 
1) Amendments in the field of labour legislation (adopting new or amending and supplementing the existing laws) in order to overcome the said problems, dilemmas, or for the purpose of closer and more comprehensive regulation of the said issues;

2) Using more possibilities related to conclusion of agreements on association of trade unions, or associations of employers, in order to fulfil the condition on representation and participation in collective bargaining, i.e. conclusion of a collective agreement pursuant to the provisions of Article 249 of the Labour Act;

3) Using more possibilities related to conclusion of agreements on regulating earnings, compensation of earnings and other income of employees, pursuant to Article 250 of the Labour Act (not only in case a trade union is not established at an employer but also in case the trade union is established but not acknowledged as a representative one); ${ }^{24}$

4) Greater and more frequent involvement of conciliators in the process of collective bargaining in order to provide expert and other possibly required assistance to negotiating parties, and ensure further affirmation of basically preventive conciliating mission in order to improve negotiating process, increase effects of collective bargaining and reduce disputes between employers and employees; ${ }^{25}$

5) Establishing permanent tripartite or multipartite body at the level of the Republic of Serbia, for the purpose of monitoring the implementation of regulations on social partnership and collective bargaining, and harmonizing practice in this important field of social life; ${ }^{26}$

6) Greater media and other support to the efforts aimed at accomplishing the envisaged goals and tasks in the interest of employers, employees, the state and the society as a whole.

24 The provision of Article 250 para. 1 of the Labour Act is illogical and incomplete. It excludes the possibility to conclude an agreement to regulate earnings, compensations of earnings and other income of employees if there is a trade union of any kind at an employer, regardless of the fact that it is not representative. The envisaged goals cannot be fulfilled completely if the existing wording is not expanded to include the employers where there is one or more (small) non-representative trade unions, which is often the case in practice. 25 The possibility of conciliator's participation in collective bargaining should be additionally strengthened and recognized, both by legal regulations and in another appropriate manner.

26 Multipartite character of the proposed body is maybe more acceptable because in addition to the representatives of state, employers and employees it could also include neutral experts, as well as other possible subjects who could contribute to its successful operation with their knowledge and experience in the interest of all parties involved. 


\section{References}

Text-books, Monographs and Scientific Articles

Baturan, L., Maksimović B. \& Đuričić, J. (2014): Jednakost plaćanja muške i ženske radne snage za jednak rad, Zbornik radova Pravo i društvena stvarnost, vol. II, Kosovska Mitrovica: Pravni fakultet Univerziteta u Prištini sa privremenim sedištem u Kosovskoj Mitrovici.

Begović B., Labus M. \& Jovanović A. (2011): Ekonomija za pravnike (3rd edition). Beograd: Pravni fakultet Univerziteta u Beogradu.

Kulić Ž. (2003): Upravljanje ljudskim resursima sa organizacionim ponašanjem, Beograd.

Milošević G. (2016), Osnovi ekonomije, Novi Sad: Pravni fakultet Univerziteta u Novom Sadu.

Veselinović P. (2010), Ekonomija, Beograd.

Legislation

Ustav Republike Srbije (Constitution of the Republic of Serbia), Službeni glasnik Republike Srbije, br. 98/2006.

Zakon o radu (Labor Act), Službeni glasnik Republike Srbije, br. 24/2005, 61/2005, 54/2009, 32/2013, 75/2014. 


\title{
Др Живко Кулић,
}

Редовни професор Правног факултета,

Универзитет Мегатренд

Др Горан Милошевић,

Редовни професор Правног факултета,

Универзитет у Новом Саду

\section{Др Лука Батуран,}

Асистент са докторатом Правног факултета,

Универзитет у Новом Саду

\section{ТРЖИШТЕ РАДА И КОЛЕКТИВНО ПРЕГОВАРАЊЕ У РЕПУБЛИЦИ СРБИЈИ}

\begin{abstract}
Резиме
И поред прокламоване равноправности и једнакости субјеката на тржишту рада, радник је фактички слабија страна у систему колективног преговарања. Због свог економског, материјалног и социјалног положаја у друштву, његова позиција у процесу преговарања и уговарања услова рада и запослења не може се изједначити с позицијом власника капитала, нарочито у случајевима колективног преговарања на нивоу послодавца. С повећањем нивоа колективног преговарања појачава се и позищија радничке, односно синдикалне преговарачке стране. Снага синдиката мање долази до изражаја на нивоу предузећа него на гранском и националном нивоу. На вишим нивоима колективног преговарања синдикат успешније штити права и интересе свог чланства и радника у целини.
\end{abstract}

Кључне речи: синдикат, запослени, послодавац, колективно преговарање, колективни уговор, регионални развој. 
